\title{
Calculating the Soil Surface Nitrogen Balance at Regional Scale: Example Application and Critical Evaluation of Tools and Data
}

\author{
Luca Bechini*, Nicola Castoldi \\ Dipartimento di Produzione Vegetale, Università di Milano \\ Via Celoria 2, 20133 Milano, Italy
}

\begin{abstract}
Agro-ecological indicators (AEIs) allow evaluating sustainability for a large number of farms. The SITPAS Information System developed for the agricultural park "Parco Agricolo Sud Milano" (northern Italy) contains detailed farming and cropping systems information for 731 farms that can be used for these analyses. We used the SITPAS database to evaluate $\mathrm{N}$ management with an AEI and to evaluate the suitability of the SITPAS data model for this type of applications. The AEI (soil surface $\mathrm{N}$ balance) was calculated for each crop at field scale, as the difference between the sum of $\mathrm{N}$ inputs (atmospheric depositions, biological fixation, fertilisers, residues from previous crop) and crop $\mathrm{N}$ uptake; the results were aggregated at rotation and farm levels. The farming systems with the highest surplus (> $300 \mathrm{~kg} \mathrm{~N} \mathrm{ha}^{-1}$ ) are dairy, cattle and pig farms, in which chemical $\mathrm{N}$ fertilisers are used in addition to animal manures. The crops with the highest surplus are Italian ryegrass and maize (183 and $172 \mathrm{~kg} \mathrm{~N}^{-1}$, respectively), while rice and wheat have the lowest surplus ( 87 and $85 \mathrm{~kg} \mathrm{~N} \mathrm{ha}^{-1}$ ). The data model allowed to store and analyse complex information not manageable otherwise; its main limitation was the excessive flexibility, requiring a complicated procedure for the calculations of this example, and the exclusion of most data at the farming systems level (corresponding to $82 \%$ of the studied area) for missing, incomplete, out-of-range or inconsistent data. These results suggest to promote actions towards better $\mathrm{N}$ management in cropping systems in the Park and to develop simple data models based on minimum data requirements when sustainability evaluations are to be conducted.
\end{abstract}

Key-words: agricultural park, agro-ecological indicators, animal farms, geographical information systems, relational databases.

\section{Introduction}

In the last decades, there has been an increasing concern about the environmental impact of agricultural activities, involving consumers, citizens, policy makers and farmers. Several policy measures to promote sustainable agriculture were issued by European Union, governments and regional administrations. As a support to ex-post and ex-ante evaluation of these measures, it is important to evaluate the sustainability of agricultural management, to reveal not only the systems which are negatively affecting the environment, but also to identify the positive environmental externalities of agricultural activities. Such evaluations need to be carried out for a large number of farms. To be feasible, they should be based on data already available without the implementation of direct measures, which would be too expensive for non-experimental contexts. Examples of available data include Common Agricultural Policy (CAP) archives, applications for funding under the Rural Development Programmes and demands of agricultural fuel.

The most suitable tools that can be applied in this context are agro-ecological indicators (AEIs). These (OECD, 2001; Castoldi and Bechini, 2006) are synthetic variables representing the cropping or farming systems, based on relatively simple data, allowing evaluating the environmental performance of production systems by benchmarking with thresholds and providing relative comparisons of systems in space and time. Issues that can be faced with AEIs include biodiversity and landscape (Weinstoerffer and Girardin, 2000), water quality, nutrient (Parris, 1998; Öborn et al., 2003) and pesticide man- 
agement (Reus et al., 2002), and soil quality (Bockstaller and Girardin, 1996).

Our application of AEIs is based on the SITPAS information system ("Sistema Informativo Territoriale per il Parco Agricolo Sud Milano", standing for "Agricultural Information System for the Sud Milano Agricultural Park"; Bechini and Zanichelli, 2000; Provincia di Milano, 2006). The SITPAS information system integrates in the same GIS environment agricultural, pedological, climatic and environmental information collected in the Parco Agricolo Sud Milano (PASM). In particular, it contains detailed and georeferenced crop management information for 731 farms, obtained through direct interviews with farmers.

In this paper (i) we present the SITPAS database, underlining its specific features in relation to the calculation of AEIs indicators of crop management; (ii) we evaluate one aspect of sustainability using a management-based AEI, the soil surface balance for nitrogen (N) (Parris, 1998), applied to the farms described in the SITPAS database; (iii) we finally discuss advantages and disadvantages of this approach.

\section{Materials and methods}

\subsection{The SITPAS information system}

The PASM is a regional metropolitan agricultural Park, surrounding the town of Milano (northern Italy, $45^{\circ} \mathrm{N}, 9^{\circ} \mathrm{E}$ ), and including $61 \mathrm{mu}-$ nicipalities. It was created in 1990 with the aim of preserving and improving landscape and natural environment, and, differently than in traditional protected areas, also to safeguard, qualify and promote agro-forestry activities. The agricultural area is ca. 35,000 ha, and the most important crops are maize, rice, permanent meadows, soybean, barley, Italian ryegrass and winter wheat, with moderate to high yields (averages of 9.6, 19.5, 5.2, 4.8, 4.9 and 3.0 t DM ha ${ }^{-1}$ for grain maize, silage maize, rice, winter wheat, barley and soybean, respectively). A total of 910 farms has been identified, and 731 were described in detail; of these, animal farms are 348 and raise bovine (dairy and cattle), swine and poultry livestock. Irrigation is normally performed with surface methods, using water from a dense network of canals.

The aim of the SITPAS project (1999-2003) was to collect, integrate and analyse information about agricultural activities in the PASM to support strategic and operational decisions of the Park. The SITPAS information system was developed in a GIS environment and includes vector maps representing polygons at the cadastral and municipal level and several relational databases. The databases consist of the farming systems database (SITPAS-db), containing data collected through interviews to 731 farmers, and the external pre-existing databases (including databases of public administration, like CAP files).

\subsection{The SITPAS database}

The SITPAS-db contains information collected on purpose during the project and not available in any other external pre-existing database. Its data model was developed with the entity-relationship framework (Garcia-Molina et al., 2002). It is consistent with the questionnaire used to interview the farmers, and is linked with external data sources (databases and maps). It was implemented using the Relational Database Management System (RDBMS) Microsoft Access. The implementation includes 159 entities, 166 domains (closed lists containing qualitative information, used to avoid typing errors and to ensure data consistency within the working group) and 150 relations. The database contains detailed information related to farm, cultivated parcels, irrigation sources, buildings used for agricultural production, mechanization, crop rotations and management, livestock management (feed, manure). Every crop and animal management information represents the farmer's average behaviour, and therefore is not related to a particular year. All information related to buildings, cultivated land and crop operations are georeferenced at the cadastral parcel level. The application presented here is related to crop management, therefore details are provided for this section of the data model. A farm may run one or more crop rotations, which can be georeferenced by indicating the cadastral parcel(s) used; if the parcels are not identified, the rotation is referred to the entire farm. Crop rotations are represented as a sequence of crops over time; for each crop, agronomic operations can be recorded (tillage, sowing, fertilisation, irrigation, herbicide, fungicide and insecticide application, harvest). For each crop management 
operation several types of information can be specified: the type of operation, the date on which an operation is carried out (which can be indicated with the day and month or by specifying the number of days before or after another crop operation or before/after a crop development stage), the percentage of crop area $\left(\mathrm{R}_{\mathrm{a}}\right)$ interested by a given crop management operation (less than or equal to $100 \%$ ), the frequency (f) with which a crop management operation is repeated during the growing season (e.g. cutting of meadows), the depth of tillage. For operations involving the application of one or more products (fertilisers or pesticides), the type and amount of product(s) applied are indicated; for each product, the detailed composition is available in the database (e.g. N, P and $\mathrm{K}$ contents of fertilisers, active ingredients of pesticides), through a list that can be expanded. For harvest operations, the yield(s) and the fate of harvested product(s) and residues can be specified (sold, recycled within the farm - for example as animal feed -, re-incorporated into the soil).

The flexibility of this data model needs also to be described: farmers presented a wide range of responses, not only in technical terms, but also concerning the amount and the quality of the information provided. This reflects the variability of production systems and the variability of farmers' technical skills and willingness to collaborate. We believe that this variability is difficult to avoid when the number of farms is large and the less co-operative farmers are not excluded from the survey. Therefore, in order to maximize the possibility of using different types of data, the data model described above was kept flexible, so that for example it is possible to: (i) leave several fields empty (e.g. crop yields and the amounts of products applied do not need to be always specified); (ii) avoid inserting the entire set of crop management operations (e.g. specifying a harvest operation is not mandatory, or the harvest operation can be specified but the products obtained do not need to be listed); (iii) use different measurement units for the same variable in different records (e.g. crop yield can expressed on a wet or dry basis); (iv) use hierarchical domains to specify crop types, types of management operation, types of products applied: the hierarchical domains allow to specify the value of a variable at different levels of detail (e.g. crop type can be described as "Cereals", or "Maize", or "Maize FAO Class 600" or "Maize - Costanza"); (v) store the same information in alternative ways; e.g. straw incorporation can be either described as a distinct crop management operation or as the fate of the straw resulting from a grain harvest operation.

\subsection{Calculation of $N$ surplus}

The soil surface $\mathrm{N}$ balance indicator (Parris, 1998) was separately calculated for each single crop of each rotation of each farm, and then a weighted average (based on crop area) was calculated for the rotation and for the farm. This indicator is the difference between the nutrients entering the soil and those leaving the soil with crop uptake annually. Positive values of the balance indicate nutrient accumulation in soil and/or nutrient losses, while negative values indicate nutrient depletion from soil. We calculated the soil surface $\mathrm{N}$ balance as:

$$
\mathrm{S}=\mathrm{F}+\mathrm{M}+\mathrm{R}_{\mathrm{P}}+\mathrm{A}+\mathrm{B}-\mathrm{R}-\mathrm{U}
$$

where: $\mathrm{S}=\mathrm{N}$ surplus, $\mathrm{F}=\mathrm{N}$ applied with chemical fertilisers, $R_{P}=N$ returned to soil with residues originating from the previous crop in the rotation, $\mathrm{M}=\mathrm{N}$ applied with animal manures, $\mathrm{A}=$ atmospheric depositions, $\mathrm{B}=$ biological fixation of leguminous crops, $\mathrm{R}=\mathrm{N}$ removed from soil with crop residues, $\mathrm{U}=\mathrm{N}$ removed from soil with useful product.

Nitrogen contained in irrigation water, ammonia volatilisation and denitrification were not considered because not enough information was available to estimate them. Denitrification and ammonia volatilisation are therefore a part of $\mathrm{N}$ surplus, and contribute to possible losses. The quantity $\mathrm{F}$ was estimated by multiplying the amount of fertilisers applied by their $\mathrm{N}$ concentration. For animal manures, both the amounts applied and the $\mathrm{N}$ concentrations were unknown. To estimate the amount of manure-N available at the field level, we calculated for each farm the total livestock weight (using the number of heads in each animal group and their average live weight). On this basis, we then estimated the annual $\mathrm{N}$ emissions from livestock, using a conversion coefficient (live weight emissions), net of losses in the stable and during manure storage; it therefore represents residual $\mathrm{N}$ for field distribution (Sacco et al., 
2003). Generally, farmers did not indicate the amount of manure applied on each field; for that reason we homogeneously allocated manure-N to crops for which operations of animal manure distribution were declared; if this information was missing, we assumed that the entire farm area was fertilised with animal manures. Atmospheric deposition (A) was set at $15 \mathrm{~kg} \mathrm{~N}$ ha $^{-1}$ crop $^{-1}$ (Grignani et al., 2003). Biological fixation (B) was estimated as $\mathrm{U}-\mathrm{A}-0.5 \mathrm{M}-0.7$ F (Grignani et al., 2003) for monospecific leguminous crops (soybean, meadows), and equal to $40 \mathrm{~kg} \mathrm{~N} \mathrm{ha}^{-1}$ year $^{-1}$ for other rotated or permanent meadows (Grignani et al., 2003). We as- sumed that crop $\mathrm{N}$ uptake (U) could be estimated by multiplying the declared crop yields by their $\mathrm{N}$ concentrations derived from literature (Grignani et al., 2003). For the estimation of $\mathrm{N}$ contained in crop residues $\left(R_{P}\right.$ and $\left.R\right)$, we first calculated the amount of crop residues using yield and harvest index; we then multiplied this amount by its $\mathrm{N}$ concentration (Grignani et al., 2003).

Before carrying out the calculation of the soil surface balance, a detailed data quality check was done. This was particularly important because different persons were involved in data collection and because of the variability in farmers' responses. In particular, we have

Table 1. Data sets used for the calculation of soil surface nitrogen balance in the Sud Milano Agricultural Park: average (and standard deviations) of farms attributes.

\begin{tabular}{|c|c|c|c|c|c|c|c|}
\hline \multirow{4}{*}{$\begin{array}{l}\text { Attribute } \\
\\
\text { Number of farms } \\
\text { Total area } \\
\text { Farm area }\end{array}$} & Units & \multicolumn{2}{|c|}{$\begin{array}{l}\text { All the farms } \\
\text { of the database } \\
\text { (dataset A) }\end{array}$} & \multicolumn{2}{|c|}{$\begin{array}{l}\text { Farms with } \\
\text { complete data } \\
\text { (dataset B) }\end{array}$} & \multicolumn{2}{|c|}{$\begin{array}{c}\text { Farms with } \\
\text { positive crop } \mathrm{N} \\
\text { balances } \\
\text { (dataset } \mathrm{C})\end{array}$} \\
\hline & & \multicolumn{2}{|c|}{731} & \multicolumn{2}{|c|}{395} & \multicolumn{2}{|c|}{157} \\
\hline & ha & \multicolumn{2}{|c|}{$38,095(100 \%)$} & \multicolumn{2}{|c|}{$20,517(54 \%)$} & \multicolumn{2}{|c|}{$6,704(18 \%)$} \\
\hline & ha & 52 & $(65)$ & 52 & (66) & 43 & (43) \\
\hline \multicolumn{8}{|c|}{ Percentage area cultivated with } \\
\hline Maize & $\%$ & 46 & $(33)$ & 46 & $(32)$ & 48 & $(35)$ \\
\hline Rice & $\%$ & 17 & $(32)$ & 17 & (33) & 19 & $(35)$ \\
\hline Meadows & $\%$ & 16 & $(25)$ & 17 & (24) & 16 & (26) \\
\hline Barley & $\%$ & 5 & (14) & 5 & (13) & 2 & (11) \\
\hline Soybean & $\%$ & 4 & (13) & 5 & (16) & 6 & (20) \\
\hline Italian ryegrass & $\%$ & 3 & (11) & 3 & (12) & 3 & (12) \\
\hline Wheat & $\%$ & 2 & $(10)$ & 3 & (10) & 2 & $(7)$ \\
\hline \multicolumn{8}{|l|}{ Livestock intensity } \\
\hline Dairy & t l.w. ha-1 & 0.62 & $(1.48)$ & 0.52 & $(0.94)$ & 0.74 & $(1.15)$ \\
\hline Cattle & t l.w. ha ${ }^{-1}$ & 0.09 & $(0.32)$ & 0.09 & $(0.35)$ & 0.10 & $(0.47)$ \\
\hline Swine & t l.w. ha-1 & 0.14 & $(1.22)$ & 0.04 & $(0.30)$ & 0.05 & $(0.28)$ \\
\hline Poultry & t l.w. ha-1 & 0.01 & $(0.14)$ & 0.00 & $(0.02)$ & 0.00 & $(0.03)$ \\
\hline \multicolumn{8}{|c|}{ Percentage of area treated by contractors for } \\
\hline Harvest operations & $\%$ & 48 & $(42)$ & 48 & $(42)$ & 46 & $(43)$ \\
\hline Land management & $\%$ & 5 & $(22)$ & 4 & $(20)$ & 5 & (22) \\
\hline Tillage & $\%$ & 7 & $(24)$ & 6 & $(22)$ & 4 & $(18)$ \\
\hline Sowing & $\%$ & 11 & $(31)$ & 11 & $(31)$ & 12 & $(32)$ \\
\hline Herbicide appl. & $\%$ & 14 & $(34)$ & 14 & $(34)$ & 13 & $(34)$ \\
\hline \multicolumn{8}{|l|}{ Mechanisation } \\
\hline Machinery power & $\mathrm{kW} \mathrm{ha-1}$ & 11.0 & $(11.8)$ & 11.5 & $(13.7)$ & 12.5 & $(16.9)$ \\
\hline $\begin{array}{l}\text { Combine-harvesters } \\
\text { per farm }\end{array}$ & $\mathrm{n}$ & 0.27 & $(0.54)$ & 0.25 & $(0.49)$ & 0.25 & $(0.51)$ \\
\hline \multicolumn{8}{|c|}{ Percentage of rice area irrigated with } \\
\hline Turned irrigation & $\%$ & 2 & $(11)$ & 1 & (9) & 1 & $(8)$ \\
\hline $\begin{array}{l}\text { Delayed continuous } \\
\text { flooding }\end{array}$ & $\%$ & 7 & $(24)$ & 6 & (22) & 7 & (24) \\
\hline $\begin{array}{l}\text { Traditional continuous } \\
\text { flooding }\end{array}$ & ls $\%$ & 14 & $(33)$ & 14 & $(32)$ & 14 & (33) \\
\hline Turned flooding & $\%$ & 3 & $(16)$ & 3 & $(16)$ & 3 & $(16)$ \\
\hline
\end{tabular}


checked that all the variables required for our calculations were within a proper range and were not missing; otherwise we eliminated from the analysis the corresponding crops, rotations or farms with the exception of average crop yields, used in replacement of missing or out-ofrange yields. All the variables related to crop management operations (crop biomass and amounts of products applied) were multiplied by $R_{a} \times f$ (to consider the percentage of crop area treated with the operation and its frequency).

\section{Results}

\subsection{Data quality}

The original SITPAS-db (dataset A) describes 731 farms, covering 38,095 ha. This figure is higher than the ca. 35,000 ha of agricultural area of the Park, because it includes farms with part of the land outside the Park. Average farm-scale properties (Table 1) show that maize, rice and meadows are the most important crops (occupying on average 46,17 and $16 \%$ of farm area, respectively), and that livestock mostly belongs to the dairy type, with a moderate average density $\left(0.62 \mathrm{t}\right.$ l.w. ha $\left.{ }^{-1}\right)$. Contractors carry out harvest operations on $48 \%$ of the area, while their contribution is much smaller for sowings and herbicide distributions. Rice is mostly irrigated with the traditional continuous flooding system (on average $14 \%$ of farm area).

Three hundred thirty-six farms having at least one record with null, out-of-range or inconsistent data were excluded from analysis.
The 395 remaining farms (Table 1, dataset B), occupying 20,517 ha (54\% of the area of dataset A), maintain similar characteristics compared to the original data set. Farms were excluded for these reasons: missing indication of the amounts of fertilisers applied, incomplete description of livestock density (missing number or missing weight of animals), inconsistent declaration of farm area, crop management described only for a part of the farm, unknown exports of animal manures.

\subsection{Negative nitrogen surpluses}

Unexpectedly, several soil surface $\mathrm{N}$ balances at crop level on dataset B were negative. Surplus can be negative only when $\mathrm{N}$ removed from soil $(\mathrm{R}+\mathrm{U})$ exceeds $\mathrm{N}$ inputs to soil $\left(\mathrm{F}+\mathrm{R}_{\mathrm{P}}+\mathrm{M}+\mathrm{A}+\mathrm{B}\right)$. Crops with negative surplus show unrealistic amounts (Table 2) of $\mathrm{N}$ applied with fertilisers ( $\mathrm{F}$ and $\mathrm{M}$ ), which appear too low to sustain the reported values of crop $\mathrm{N}$ uptake $(\mathrm{R}+\mathrm{U})$. These farmers have probably underestimated $\mathrm{N}$ inputs, for example by not declaring one or more fertiliser applications. Another error could be an under-estimation of biological fixation (B) for meadows, which represent a relevant fraction of the area affected by this problem. We decided to exclude from analysis the farms with negative surplus for one or more crops: the smaller dataset obtained (C; Table 1) includes 157 farms ( $18 \%$ of the area of dataset A) and maintains similar characteristics to A, even with a smaller average farm size ( 43 vs. 52 ha), a higher portion of farm area cultivated with maize and rice, and different livestock densities (higher for dairy and lower for swine). We will now analyse dataset $\mathrm{C}$ at whole-farm level.

Table 2. Soil surface nitrogen balance for crops with negative N surplus in the Sud Milano Agricultural Park: average (and standard deviation) of components and surplus.

\begin{tabular}{|c|c|c|c|c|c|c|c|c|c|c|}
\hline Crop type & $\begin{array}{c}\text { Total area } \\
\text { in dataset } \\
\text { A }\end{array}$ & $\begin{array}{l}\text { Crop area } \\
\text { with negative } \\
\mathrm{N} \text { surplus }\end{array}$ & $\mathrm{U}$ & $\mathrm{R}$ & $\mathrm{R}_{\mathrm{P}}$ & $\mathrm{F}$ & M & A & B & $\mathrm{S}$ \\
\hline & \multicolumn{2}{|c|}{$\longrightarrow$ (ha) } & \multicolumn{8}{|c|}{$\left(\mathrm{kg} \mathrm{N} \mathrm{ha}^{-1}\right)$} \\
\hline Maize & 16408 & $2494(15 \%)$ & $182(47)$ & $51(26)$ & $37(27)$ & $66(82)$ & $14(44)$ & 15( & $0(0)$ & $-100(70)$ \\
\hline Rice & 10545 & 1940 & & $36(7)$ & $27(15)$ & $23(25)$ & $1(7)$ & 15 & $0(0)$ & $-44(21)$ \\
\hline Meadows & 4328 & $1547(36 \%)$ & $224(58)$ & $0(0)$ & $2(9)$ & $9(24)$ & $39(63)$ & $15(0)$ & $40(0)$ & $-119(68)$ \\
\hline Wheat & 985 & $541(55 \%)$ & $119(26)$ & $30(4)$ & $22(20)$ & $40(41)$ & $0(0)$ & $15(0)$ & $0(0)$ & $-72(50)$ \\
\hline Barley & 1243 & $518(42 \%)$ & $93(32)$ & $21(6)$ & $22(23)$ & $22(28)$ & $0(0)$ & $15(0)$ & $0(0)$ & $-54(44)$ \\
\hline Italian ryegrass & s 1026 & $296(29 \%)$ & 99 (12) & $2(8)$ & 16 (19) & $6(15)$ & $4(15)$ & $15(0)$ & $0(0)$ & $-59(24)$ \\
\hline
\end{tabular}

$\mathrm{U}=\mathrm{N}$ removed from soil with useful product, $\mathrm{R}=\mathrm{N}$ removed from soil with crop residues, $\mathrm{R}_{\mathrm{P}}=\mathrm{N}$ returned to soil with residues originating from the previous crop in the rotation, $\mathrm{F}=\mathrm{N}$ applied with chemical fertilisers, $\mathrm{M}=\mathrm{N}$ applied with animal manures, $\mathrm{A}$ $=$ atmospheric depositions, $\mathrm{B}=$ biological fixation of leguminous crops. 


\subsection{Nitrogen surplus}

Whole-farm level. Nitrogen surpluses of dataset $\mathrm{C}$ have large variability (Table 3 ); the number of farms decreases with increasing levels of $\mathrm{S}$. Moving from the first to the last class of $\mathrm{N}$ surplus (Table 3), the amount of $\mathrm{N}$ applied with manure (M) systematically grows; $\mathrm{N}$ applied with fertilisers (F) and crop $\mathrm{N}$ uptake do not follow a clear trend; at high levels of surplus, $\mathrm{F}$ is not increasing and $U$ is always higher than $190 \mathrm{~kg} \mathrm{~N} \mathrm{ha}{ }^{-1}$. The output/input ratio is decreasing from 0.86 to 0.34 . The first four classes $\left(0-200 \mathrm{~kg} \mathrm{~N} \mathrm{ha}^{-1}\right)$ occupy together $70 \%$ of the studied area, while extremely high surpluses (> $300 \mathrm{~kg} \mathrm{~N} \mathrm{ha}^{-1}$ ) cover $14 \%$ only. In the classes with low surplus $\left(0-100 \mathrm{~kg} \mathrm{~N} \mathrm{ha}^{-1}\right)$ the quantities of $\mathrm{N}$ applied with $\mathrm{F}$ and $\mathrm{M}$ are similar to crop $\mathrm{N}$ uptake $(\mathrm{U}+\mathrm{R})$; these farms have negligible or low livestock densities (below the average for the entire Park); a relevant fraction of farm area (29 and $33 \%$ on average in the first two classes) is cropped with rice. In the classes with intermediate surplus (100-200 kg N ha $\left.{ }^{-1}\right)$ crop uptake and $\mathrm{F}$ increase, together with $\mathrm{M}$. Compared to previous classes, these farms have more intensive dairy farming (0.3 and $1.2 \mathrm{t}$ l.w. ha $^{-1}$ ), cultivate more maize, more meadows and less rice. Over $200 \mathrm{~kg} \mathrm{~N}^{-1}$ of surplus, the excess is mostly determined by a relevant amount of $\mathrm{N}$ applied in the form of manure; this classes show relatively low $\mathrm{F}$ amounts and high crop uptakes. They include intensive dairy farms (2.7 t l.w. ha ${ }^{-1}$ in the last class) associated with cattle and / or swine breds. The production of forages is provided by maize, meadows and Italian ryegrass.

Rotation level. The results for rotations including crops having positive surplus are presented in table 4; the total area considered is higher than in the case of single farms due to a smaller number of crop excluded. Again, the highest surpluses are driven by relevant amounts of $\mathrm{N}$ applied with manures, in rotations including forages. Cereal rotations (with or without rice) occupy a relevant portion of the area and have the lowest surpluses $\left(87-141 \mathrm{~kg} \mathrm{~N}^{-1}\right.$ on average).

Crop level. When the results are analysed at the level of crop types (Table 5, describing all crops with positive $\mathrm{S}$ ), more information can be ex-

Table 3. Soil surface nitrogen balance for farms without negative crop N surplus in the Sud Milano Agricultural Park: average (and standard deviation) of components and surplus.

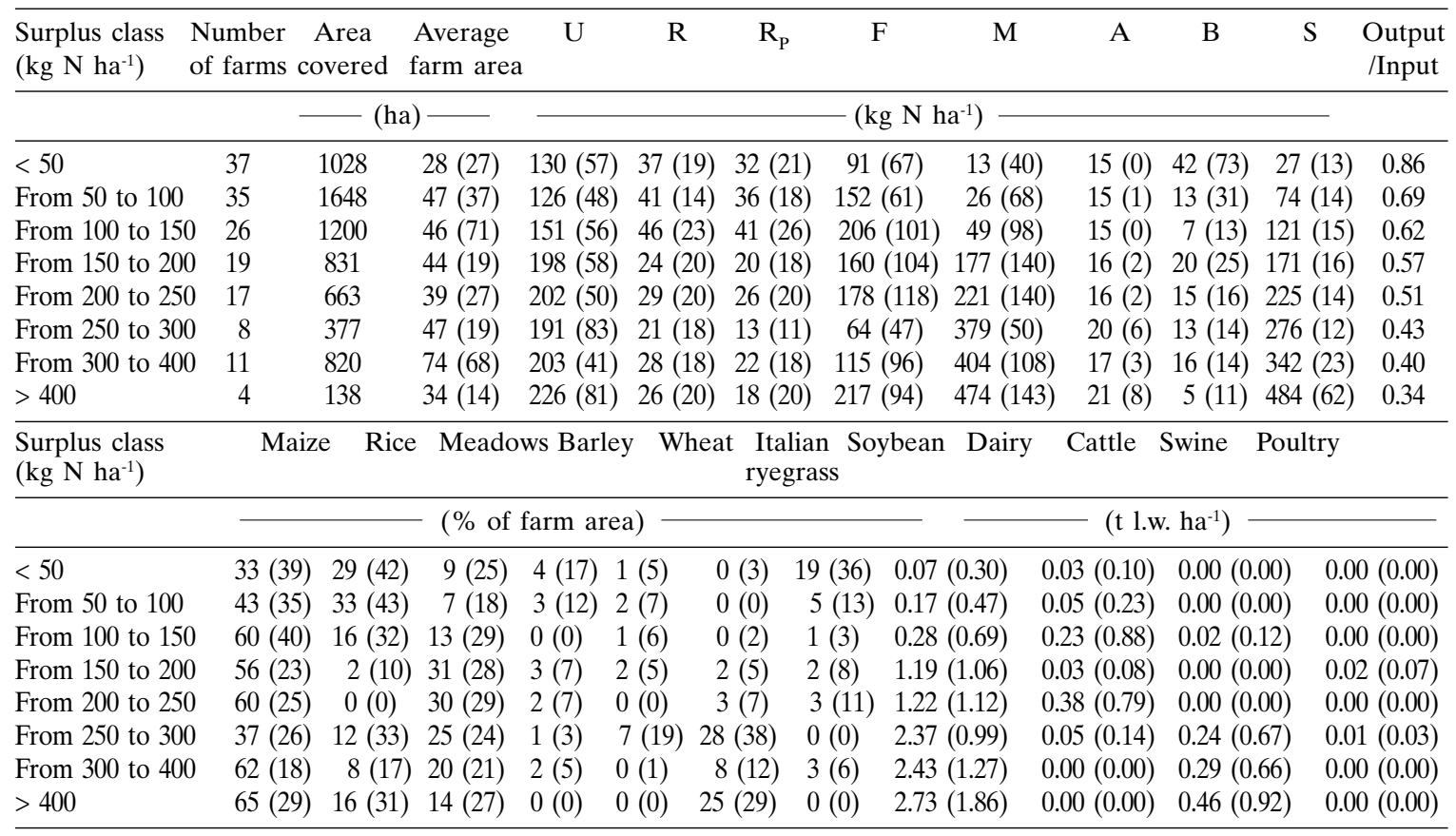

For symbols, see Table 2 . 
Table 4. Soil surface nitrogen balance for rotations without negative crop N surplus in the Sud Milano Agricultural Park: average (and standard deviation) of components and surplus.

\begin{tabular}{|c|c|c|c|c|c|c|c|c|c|c|c|}
\hline $\begin{array}{l}\text { Type of } \\
\text { rotation }\end{array}$ & $\begin{array}{c}\text { Total } \\
\text { area in } \\
\text { dataset }\end{array}$ & $\begin{array}{c}\text { Rotation } \\
\text { area } \\
\text { A analysed }\end{array}$ & $\mathrm{U}$ & $\mathrm{R}$ & $\mathrm{R}_{\mathrm{P}}$ & $\mathrm{F}$ & M & A & B & $\mathrm{S}$ & $\begin{array}{c}\text { Output } \\
\text { Input }\end{array}$ \\
\hline & \multicolumn{3}{|c|}{ (ha) } & \multicolumn{8}{|c|}{$\left(\mathrm{kg} \mathrm{N} \mathrm{ha}^{-1}\right)$} \\
\hline Cereals & 8181 & $2823(35 \%)$ & $152(47)$ & $52(19)$ & $43(24)$ & $218(86)$ & $68(124)$ & $15(1)$ & $1(9)$ & $141(110)$ & 0.59 \\
\hline Cereals and rice & 11755 & $2690(23 \%)$ & $77(35)$ & $33(11)$ & $28(16)$ & 99 (59) & $53(115)$ & $15(0)$ & $3(18)$ & 87 (106) & 0.56 \\
\hline $\begin{array}{l}\text { Permanent } \\
\text { meadows }\end{array}$ & 3504 & $1122(32 \%)$ & $192(88)$ & $0(0)$ & $0(0)$ & $20(52)$ & $229(144)$ & $15(0)$ & $46(39)$ & 119 (103) & 0.62 \\
\hline $\begin{array}{l}\text { Cereals and } \\
\text { industrial crops }\end{array}$ & 6872 & $670(10 \%)$ & $164(38)$ & $45(12)$ & $40(12)$ & $124(63)$ & $74(132)$ & $15(0)$ & $71(46)$ & $115(98)$ & 0.65 \\
\hline $\begin{array}{l}\text { Cereals and } \\
\text { forages }\end{array}$ & 2106 & $656(31 \%)$ & $202(63)$ & $37(15)$ & $21(21)$ & $174(67)$ & $253(148)$ & $18(4)$ & $9(19)$ & $237(146)$ & 0.50 \\
\hline $\begin{array}{l}\text { Forages and } \\
\text { cereals }\end{array}$ & 3201 & $655(20 \%)$ & $239(53)$ & $28(11)$ & $21(13)$ & $175(134)$ & 325 (139) & $20(5)$ & $6(12)$ & $280(98)$ & 0.49 \\
\hline Forages & 1947 & $517(27 \%)$ & $261(97)$ & $11(11)$ & $10(10)$ & $103(90)$ & 285 (219) & $19(6)$ & $80(140$ & 226 (186) & 0.55 \\
\hline
\end{tabular}

Cereals: rotation including maize, winter wheat, barley, oat, rye and eventually rice (less than $10 \%$ of the area).

Cereals and rice: from 10 to $100 \%$ of rotation area is cropped with rice.

Cereals and industrial crops: at least $10 \%$ of rotation area is cropped with sugar beet, oil or protein crops.

Cereals and forages: more than half of the area is cropped with cereals and forages are at least $10 \%$ of the area.

Forages and cereals: more than half of the area is cropped with forages and cereals are at least $10 \%$ of the area.

Forages: the rotation has only forages.

For symbols, see Table 2.

Table 5. Soil surface nitrogen balance for crops having positive surplus in the Sud Milano Agricultural Park: average (and standard deviation) of components and surplus.

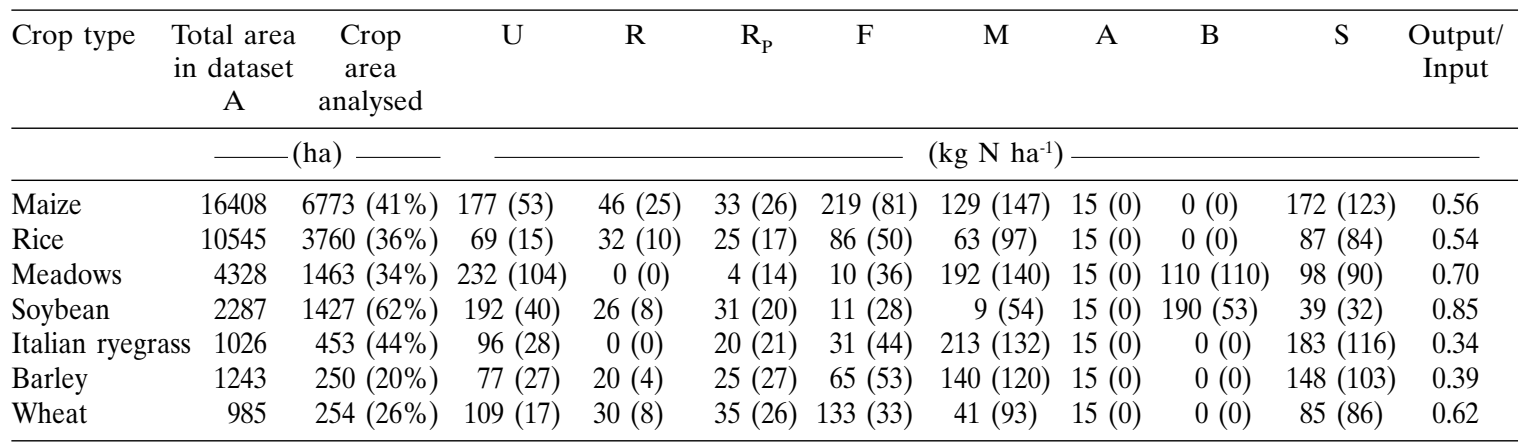

For symbols, see Table 2.

tracted from the database compared to the whole-farm and rotation levels: the fraction of area analysed compared to total area cultivated in the Park ranges from $20 \%$ for barley to $62 \%$ for soybean.

Italian ryegrass and maize have the highest surplus (183 and $172 \mathrm{~kg} \mathrm{~N} \mathrm{ha}^{-1}$ ), deriving from high $\mathrm{F}$ and $\mathrm{M}$ applications exceeding crop uptake. Rice has a much lower surplus, because farmers tend to use less chemical fertilisers and animal manures. Meadows have high crop uptake and are mostly fertilised with manures, with a small contribution of mineral $\mathrm{N}$. The two winter cereals (wheat and barley) are fertilised with opposite strategies, more based on animal manures for barley and on chemical $\mathrm{N}$ fertilisers for wheat. Italian ryegrass is the crop where the highest amount of $\mathrm{N}$ from animal manures is used (213 $\mathrm{kg} \mathrm{N} \mathrm{ha}^{-1}$ on average).

\section{Discussion}

\subsection{Nitrogen surplus}

From our results the systems more at risk appear to be the forage and grain crops (Italian ryegrass, maize, barley and meadows) cultivated in dairy and pig farms, where the amounts 
of $\mathrm{N}$ applied with animal manure are in general very high, and chemical $\mathrm{N}$ fertilisers not reduced accordingly. Farming systems with high surplus do not represent a large portion of the studied area and could receive technical assistance for better $\mathrm{N}$ management. Our results are in agreement with those found by other $\mathrm{Au}$ thors, both for average and for variability. Schröder et al. (1996) have found an average value for surplus of $160 \mathrm{~kg} \mathrm{~N} \mathrm{ha}^{-1}$ for $38 \mathrm{Dutch}$ integrated arable farms, and 117 after the adoption of an integrated nutrient management program. The variability was elevated, with surpluses ranging from less than 50 to more than $200 \mathrm{~kg} \mathrm{~N} \mathrm{ha}^{-1}$. In an area with intensive animal husbandry ( $3.80 \mathrm{t}$ l.w. ha ${ }^{-1}$ on average for dairy farms), Sacco et al. (2003) have found N surpluses of $41 \mathrm{~kg} \mathrm{~N} \mathrm{ha}^{-1}$ for non-livestock farms and of $326 \mathrm{~kg} \mathrm{~N} \mathrm{ha}^{-1}$ for dairy farms. There is a good correspondence in terms of surplus between their dairy farms and our surplus class at $300-400 \mathrm{~kg} \mathrm{~N} \mathrm{ha}^{-1}$, with lower $\mathrm{M}$ values in our work (404 instead of their 426), and similar crop uptakes. Their figures are similar also for nonlivestock farms $\left(\mathrm{S}=41 \mathrm{~kg} \mathrm{~N} \mathrm{ha}^{-1}\right)$ and for crop balances $(\mathrm{S}=183,132,129,104$ and $58 \mathrm{~kg} \mathrm{~N}$ $\mathrm{ha}^{-1}$ for maize, wheat, barley, grassland and soybean, respectively).

In animal farms the uncertain concentration of $\mathrm{N}$ in manure and its uncertain availability to crops make the use of chemical $\mathrm{N}$ a cheap method to sustain crop production regardless of the fate of the animal $\mathrm{N}$ applied (the so called "insurance N": Schröder et al., 2000). For this reason methods should be identified and disseminated to the farmers of the Park to allow them for quick estimates of the nutrient value of animal manures (e.g. Scotford et al., 1998; Reeves and Van Kessel, 2000; Van Kessel and Reeves, 2000; Marino et al., 2005a; Marino et al., 2005b). Also, methods to reduce the use of chemical $\mathrm{N}$ fertilisers should be applied (e.g. for maize Magdoff, 1991; Schröder et al., 2000).

The variability of $S$ and balance components within farm groups, rotations and crop types was very large (Tables 3, 4 and 5), in particular for $\mathrm{M}$ and $\mathrm{F}$; the variability decreased at the level of crop types (e.g. for $\mathrm{F}$ in maize). Consequently, for further studies attention should be given to balance components with the highest variability, like manure. In addition, the variability demonstrates that a given crop (e.g. maize) or a given farming system (e.g. dairy farming) is not dangerous per se, but can be more or less harmful depending on the specific operational and strategic management choices taken by the farmer.

\subsection{Advantages and disadvantages of the indicator}

The interest of the indicator lies in its simplicity, because it allows the calculation using data that can be obtained without carrying out any direct measure, and to integrate aspects of nutrient management that are strictly interconnected (chemical fertiliser and animal manure applications, crop yields and uptake, etc.). The balance allows comparisons in time (the same system in different periods) and space (different cropping / farming systems of a region in the same period). The comparisons can be made on single balance components and on the resulting surplus (e.g. OECD, 2001, for different nations in different periods). OECD (2001) shows also that the balance allows to quickly assess the relative importance of different inputs (e.g. organic vs. inorganic fertilisers) in the determination of the surplus. Finally, nutrient balances can be used to create awareness among farmers and to guide improvements in crop and livestock $\mathrm{N}$ management, as demonstrated for example by Schröder et al. (1996) and by Hanegraaf and den Boer (2003).

However, several limitations must be pointed out. Nitrogen losses are the result of complex dynamic processes that are not entirely captured by a simple mass balance: among the factors that a balance does not consider, we may cite water dynamics, initial soil content of inorganic $\mathrm{N}$, soil mineralisation rate, type and $\mathrm{C} / \mathrm{N}$ ratio of crop residues and manures, tillage practices, climate, and soil characteristics. As a result, positive $\mathrm{N}$ surplus do not necessarily indicate $\mathrm{N}$ losses, mainly because different forms of $\mathrm{N}$ accumulation in the soil are possible; also, ammonia volatilisation was not taken into account in our calculation. Therefore, the indicator only shows the potential for environmental damage or unsustainable use of soil resources (OECD, 2001). It has been shown (e.g. Salo and Turtola, 2006; Sieling and Kage, 2006) that the soil surface balance does not estimate the actual $\mathrm{N}$ losses in a specific year: $\mathrm{N}$ can be accumulated in the soil so that the excess applied to a crop may be actually leached during the fallow or during 
the cultivation of the subsequent crop, or being absorbed by the next crop, or not being lost if immobilised in organic form. The surplus is an indicator for total $\mathrm{N}$ losses only if it is integrated over a relatively long period (Öborn et al., 2003); even then, losses account only for a part (15-57\%) of actual surplus (Salo and Turtola, 2006). When other regressors (e.g. precipitation, runoff, drainage) are used together with surplus to estimate losses, the variability explained is higher (Salo and Turtola, 2006). In addition, a small excess of $\mathrm{N}$ applied is unavoidable, due to the efficiency of chemical and organic fertilisers (Grignani et al., 2003), which is frequently in the range $50-70 \%$.

The nitrogen indicators proposed by Bockstaller and Girardin (2000) and by Pervanchon et al. (2005) represent an answer to most of these critical aspects, still avoiding the complexity of dynamic simulation models. They provide a semi-dynamic representation of $\mathrm{N}$ cycling in the soil-crop system, using a more processbased approach to estimate $\mathrm{N}$ volatilisation and leaching, and over-winter soil $\mathrm{N}$ dynamics. Compared to $\mathrm{N}$ balances, these indicators allow analysing the interactions that simple balances do not consider. The drawback is that they require more data about climate, soil, and crop management (fertiliser application methods and dates in particular) and that a relatively more complex calculation is needed.

In our application, several sources of uncertainty have arisen: first, the farmers frequently do not know the yields of crops that are neither sold nor weighted (e.g. silage maize and meadows); therefore, these should be measured because their variability is potentially high. Biological fixation was estimated in a simple way, but other methods should be explored to derive figures that are more accurate. Nitrogen in animal excreta was estimated on the basis of live weight, using parameters that do not consider the variability of feed ration. Crop nitrogen concentrations were assumed to be the same for all crops considered, and $\mathrm{N}$ uptake could have been overestimated for the less fertilised crops. Ammonia volatilisation was not estimated. A fieldby-field estimate of the amounts of manure applied was not available and the homogeneous allocation across farm area (the only solution in this case, as stated also by Sacco et al., 2003) might have introduced a bias for some crops, probably by overestimating $\mathrm{M}$ for winter crops and underestimating for summer crops. Finally, other Authors calculate the $\mathrm{N}$ balance in a different ways (e.g. residues, biological fixation, atmospheric depositions, and seeds are not always included). It is important therefore to note that the results are more adequate for relative comparisons rather than for estimating absolute values of $\mathrm{N}$ losses.

\subsection{Farm survey and data base management}

The use of a relational database for this type of applications is a mandatory requirement, due to the large amount of data to be stored and processed, and to the complexity of the relationships among the objects studied. Our application demonstrates that the data model developed in the SITPAS project is complete and very detailed and that the database contains agro-environmental variables related to a large agricultural area, at the detail of single cadastral parcel.

Possible improvements of the data model are related to three interconnected methodological aspects of survey and data storage: (i) flexibility of the data model, (ii) compromise between direct interviews and reliance on existing databases, and (iii) use of pre-compiled crop management itinerary.

The extreme flexibility of our data model had the great advantage of allowing almost every answer from farmers to be recorded in the database. However, this advantage had two types of adverse consequences: first, some data were very difficult to extract, in particular when the same information could be stored in alternative ways or at different hierarchical levels; second, missing data partly nullified the results of our calculations. As an example of the first consequence, to carry out the simple calculation of the soil surface balance presented here, a total of 135 queries had to be run with the RDBMS; even if this increased the time required to develop the calculations, it did not affect the possibility of using the data. For the second consequence, serious limitations became evident in our work: $82 \%$ of the studied area could not be considered at whole-farm level, and 38$80 \%$ at crop level. Apparently, one would conclude that "flexibility" means actually "lack of structure in the data", and that storing data that cannot be processed is a useless exercise. This 
is partly true, but it should be mentioned that the problem was particularly evident here due to the high level of integration required by the calculation of the indicator. To properly calculate the balance, the data needed to be completely specified for most agronomic operations of every crop of every farm. For example, even the lack of a single amount of urea applied for one out of 20 crops of a farm would require eliminating the entire farm. When less integrated information is required, much more data become available: for example, only for $15 \%$ of fertiliser applications the date was not specified, and only for $8 \%$ of inorganic fertiliser applications the amount of fertiliser was not indicated. This means that simpler but useful statistics can be successfully calculated using this database, and the flexibility is not so limiting as in the case of the balance. Our conclusion is that this flexible data model was congruent with the purpose of collecting and integrating as much information as possible on agricultural production systems of the Park during the survey. However, further studies focused on objectives that are more specific would require the development of a simpler database based on a minimum dataset, to simplify data collection and processing (Sacco et al., 2003).

As Table 1 shows, for most of the variables describing farming systems the average and the variability do not differ very much among the three datasets (A, B and C). Therefore, it would have probably been more efficient to concentrate the efforts with the most co-operative farmers to obtain management data, and to integrate this information with existing databases related to the entire set of farms in the Park. This would also answer the question if a calculation of this type can be applied at situations where the resources are not available for conducting so many direct interviews; Sacco et al. (2003), for example, have built a detailed information system on the basis of available data (CAP files, slurry management database, animal livestock register, digital cadastral map) integrated with expert knowledge for specific aspects (chemical fertiliser applications) and have carried out no interviews. This procedure has of course the advantage of being based on official data but may introduce a certain arbitrary homogeneity in some variables: for example, the variability of $F$ (Table 5) can be important, while Sacco et al. (2003) have used a fixed cropspecific value derived from expert knowledge.

Finally, the use of a standard crop management itinerary, pre-compiled by experts before the interviews are carried out, would be a useful benchmark to critically evaluate and test the data collected during the interviews, as done for example in the AGENDA project by Giupponi (2002).

\section{Concluding remarks}

The SITPAS-db is an integrated and comprehensive information base to carry out regionalscale calculations of AEIs; the powerful relational data model allows integrating and evaluating the data in a way that would not be possible otherwise. The present application showed that the procedures to collect and store the data for this type of applications can be further improved: (i) before carrying out a survey, determine precisely the objectives; a generic survey may result in too many data collected and a complex database structure; (ii) identify the minimum data required, their scale and their source; (iii) set-up the simplest data model.

The calculated indicator shows that in the study area (the Sud Milano Agricultural Park), intensive dairy and pig farming systems with excessive $\mathrm{N}$ fertilisation are potentially at risk of $\mathrm{N}$ losses, while cereal farms have lower surplus. Therefore, specific measures should be promoted by the Park for better $\mathrm{N}$ management. The most uncertain data were biological fixation, yields of meadows, nutrient emissions from livestock and their apportioning over land area. Scientific rules to determine these quantities at this scale (using easily available data) would be very useful.

The soil surface balance indicator can be used by administrative and technical bodies (e.g. by the Park) as a first screening tool, to identify the most hazardous cropping and farming systems. The balance could be calculated using available databases (CAP, manure distribution, Rural Development Programme), digital maps, remote sensed information, and expert knowledge. The indicator can also potentially be integrated with common soil and climate information (precipitation, evapotranspiration, water holding capacity) to calculate a potential nitrate 
concentration of water leaving agricultural fields (OECD, 2001). Technical assistance could be delivered to the farmers with the highest surpluses: available scientific knowledge, direct measurements and simulation models should be used to optimise agricultural management, towards reduced $\mathrm{N}$ losses and good crop yields.

\section{Acknowledgements}

The SITPAS project was funded by Parco Agricolo Sud Milano, Provincia di Milano, Camera di Commercio, Industria e Artigianato di Milano and Regione Lombardia. We gratefully acknowledge the scientific coordinator of the SITPAS project Prof. Tommaso Maggiore of the University of Milano, and Uta Biino, Daniela Bergamo, Stefano Bocchi, Marzia Cont, Matteo Penati, Maria Antonietta Polestra, Stefania Silvestri, Irene Zanichelli for the work carried out during the SITPAS project. This work was conducted under the PRIN 2004 project "Un'agricoltura per le aree protette" ("Agriculture for protected areas"), coordinated by Prof. Maurizio Borin, http://www. unirc.it/agripark, Paper n. 9. We gratefully thank all the farmers interviewed during the project for their kind collaboration.

\section{References}

Bechini L., Zanichelli I. 2000. A database for agricultural activities at farm scale for a metropolitan agricultural park. In: Christen O., Ordon F. (eds.): Book of Abstracts 3rd International Crop Science Congress, 1722 August, Hamburg, Germany, 124.

Bockstaller C., Girardin P. 1996. The crop sequence indicator: a tool to evaluate crop rotations in relation to requirements of Integrated Arable Farming Systems. Aspects of Applied Biology, 47:405-408.

Bockstaller C., Girardin P. 2000. Mode de calcul des indicateurs agro-ecologiques, Internal report INRA.

Castoldi N., Bechini L. 2006. Agro-ecological indicators of field-farming systems sustainability. I. Energy, landscape and soil management. Rivista italiana di agrometeorologia/Italian Journal of Agrometeorology, 11, 1:19-31.

Garcia-Molina H., Ullman J.D., Widom J.D. 2002. Database Systems: The Complete Book. Prentice Hall, Upper Saddle River, NJ, USA.

Giupponi C. 2002. AGeNDA: a new tool for sustainable farm management, integrated in the agri-environmental policy of the EU. In: Proceedings of the $8^{\text {th }}$ Joint Conference on Food, Agriculture and the Environment, 25-28 August, Mikana, Wisconsin, USA.

Grignani C., Bassanino M., Sacco D., Zavattaro L. 2003. Il bilancio degli elementi nutritivi per la redazione del piano di concimazione. Rivista di Agronomia, 37:155-172.
Hanegraaf C.M., den Boer D.J. 2003. Perspectives and limitations of the Dutch minerals accounting system (MINAS). European Journal of Agronomy, 20:25-31.

Magdoff F.R. 1991. Understanding the Magdoff pre-sidedress nitrate test for corn. Journal of Production Agriculture, 4:297-305.

Marino Gallina P., De Ferrari G., Bechini L., Maggiore T. 2005a. Statistiche descrittive e analisi di regressione tra le variabili compositive di un esteso campione di liquami bovini raccolti in Lombardia. In: Giuliani M.M., Gatta G. (eds.): Ricerca ed innovazione per le produzioni vegetali e la gestione delle risorse agroambientali. Atti del XXXVI Convegno della Società Italiana di Agronomia, 20-22 September, Foggia, Italy, 498-499.

Marino Gallina P., De Ferrari G., Cabassi G., Bechini L., Maggiore T. 2005b. Analisi rapida dei liquami bovini tramite spettroscopia nel vicino infrarosso: risultati ottenuti su un campione di 101 liquami eterogenei raccolti in allevamenti lombardi. In: Giuliani M.M., Gatta G. (eds.): Ricerca ed innovazione per le produzioni vegetali e la gestione delle risorse agro-ambientali. Atti del XXXVI Convegno della Società Italiana di Agronomia, 20-22 September, Foggia, Italy, 500-501.

Öborn I., Edwards A.C., Witter E., Oenema O., Ivarsson I., Withers P.J.A., Nilsson S.I., Richert Stinzing A. 2003. Element balances as a tool for sustainable nutrient management: a critical appraisal of their merits and limitations within an agronomic and environmental context. European Journal of Agronomy, 20:211-225.

OECD 2001. Environmental Indicators for Agriculture, Methods and Results, Vol 3. OECD Proceedings. OECD Publication Service, Paris, France.

Parris K. 1998. Agricultural nutrient balances as agri-environmental indicators: an OECD perspective. Environmental Pollution, 102, S1:219-225.

Pervanchon F., Bockstaller C., Amiaud B., Peigné J., Bernard P.-Y., Vertès F., Fiorelli J.-L., Plantureux S. 2005. A novel indicator of environmental risk due to nitrogen management on grasslands. Agriculture, Ecosystems and Environment, 105:1-16.

Provincia di Milano. 2006. Web site of the SITPAS project, Parco Agricolo Sud Milano, http://www.provincia.milano.it/parcosud/sitpas/index.html, verified June 30, 2006.

Reeves III J.B., Van Kessel J.S. 2000. Near-Infrared Spectroscopic Determination of Carbon, Total Nitrogen, and Ammonium-N in Dairy Manures. Journal of Dairy Science, 83:1829-1836.

Reus J., Leendertse P., Bockstaller C., Fomsgaard I., Gutsche V., Lewis K., Nilsson C., Pussemier L., Trevisan M., van der Werf H., Alfarroba F., Blümel S., Isart J., McGrath D., Seppälä T. 2002. Comparison and evaluation of eight pesticide environmental risk indicators developed in Europe and recommendations for future use. Agriculture, Ecosystems and Environment, 90:177-187.

Sacco D., Bassanino M., Grignani C. 2003. Developing a 
regional agronomic information system for estimating nutrient balances at a larger scale. European Journal of Agronomy, 20:199-210.

Salo T., Turtola E. 2006. Nitrogen balance as an indicator of nitrogen leaching in Finland. Agriculture, Ecosystems and Environment, 113:98-107.

Schröder J.J., van Asperen P., van Dongen G.J.M., Wijnands F.G. 1996. Nutrient surpluses on integrated arable farms. European Journal of Agronomy, 5:181-191.

Schröder J.J., Neeteson J.J., Oenema O., Struik P.C. 2000. Does the crop or soil indicate how to save nitrogen in maize production? Reviewing the state of the art. Field Crops Research, 66:151-164.

Scotford I.M., Cumby T.R., White R.P., Carton O.T., Lorenz F., Hatterman U., Provolo G. 1998. Estima- tion of the Nutrient Value of Agricultural Slurries by Measurement of Physical and Chemical Properties. Journal of Agricultural Engineering Research, 71:291-305.

Sieling K., Kage H. 2006. N balance as an indicator of $\mathrm{N}$ leaching in an oilseed rape - winter wheat - winter barley rotation. Agriculture, Ecosystems and Environment, 115:261-269.

Van Kessel J.S., Reeves III J.B. 2000. On-Farm Quick Tests for Estimating Nitrogen in Dairy Manure. Journal of Dairy Science, 83:1837-1844.

Weinstoerffer J., Girardin P. 2000. Assessment of the contribution of land use pattern and intensity to landscape quality: use of a landscape indicator. Ecological Modelling, 130:95-109. 